\title{
RELATOS SOBRE MAESTRAS ACOSADAS \\ E INMORALES: GÉNERO, EDUCACIÓN Y DISCIPLINAMIENTO EN EL SISTEMA ESCOLAR ARGENTINO (1919-1935) ${ }^{\alpha}$
}

\section{Stories of immoral and harassed teachers: gender, education and discipline in the school system of Argentina} (1919-1935)

\section{Adrián Cammarota ${ }^{\mathrm{B}}$}

Fecha de recepción: 16/10/2019 • Fecha de aceptación: 18/01/2020

Resumen. El trabajo tiene como objetivo analizar la relación entre género y educación, tomando como referencia el caso de tres maestras que se vieron sancionadas y dos de ellas exoneradas por supuestas infracciones morales cometidas en su vida privada. Los hechos señalados acaecieron en los años 1919, 1921 y 1935 en las provincias de Mendoza, Chubut y Río Negro, respectivamente. En uno de los expedientes avanzamos en el análisis de una denuncia de acoso cometida por personal jerárquico masculino. Entendemos que la moralidad fue uno de los pilares que sostuvo el magisterio en el campo de la educación como método de control sobre el personal docente. En esta dirección, la pesquisa aborda los mecanismos disciplinarios aplicados por el Consejo Nacional de Educación (CNE) que tendían a regular los cuerpos y las conductas ante las supuestas inmoralidades cometidas por el personal docente femenino. Trazamos un análisis descriptivo para ahondar en el campo de las representaciones, las mentalidades y los mandatos patriarcales reproducidos en el sistema escolar.

Palabras clave: género; maestras; normalismo; escuela.

\footnotetext{
${ }^{\alpha}$ Este artículo forma parte de una investigación más amplia que aborda la relación entre las comunidades locales y la escuela en la primera mitad del siglo XX en Argentina. Se agradece a los evaluadores/as designados por la revista por sus sugerencias y comentarios.

B Universidad Nacional de La Matanza. Departamento de Salud. San Justo, Buenos Aires, Argentina. adriancammarota2000@gmail.com
}

Cómo citar este artículo: Cammarota, Adrián. «Relatos sobre maestras acosadas e inmorales: género, educación y disciplinamiento en el sistema escolar argentino (1919-1935». Historia y Memoria de la Educación 12 (2020): 395-432 
Abstract. The purpose of this paper is to analyze the relationship between gender and education by taking as a reference the case of three teachers who were punished for assumed moral offences committed in their private sphere. Two of these teachers were exonerated. These events took place in 1919, 1921 and 1935 in Mendoza, Chubut and Rio Negro provinces, respectively. Furthermore, we will carry out the analysis of a file on an alleged harassment committed by senior male staff members. Morality was one of the pillars sustained in academic teacher training and served as a method of controlling the teaching staff. In many respects, this search deals with the disciplinary mechanisms applied by the Consejo Nacional de Educación (National Board of Education, CNE), which strove to regulate bodies and behavior in response to the assumed immoralities committed by the teaching staff. We develop a descriptive analysis as a way of delving into representations, mindsets and patriarchal mandates reproduced in the school system.

Keywords: gender; teachers; teacher training; school.

\section{INTRODUCCIÓN}

El trabajo tiene como objetivo analizar la relación entre género y educación, tomando como referencia el caso de tres maestras que se vieron sancionadas y dos de ellas exoneradas por supuestas infracciones morales cometidas en su vida privada. Los hechos señalados acaecieron en los años 1919, 1921 y 1935 en las provincias de Mendoza, Chubut y Río Negro, respectivamente. En uno de los expedientes avanzamos en el análisis de una denuncia de acoso cometida por personal jerárquico masculino.

Exploramos los mecanismos de intervención del otrora Consejo Nacional de Educación (en adelante CNE), ante las supuestas inmoralidades cometidas por el personal docente femenino, con base en los comentarios gestados en los pueblos donde estaban radicadas estas escuelas. Para la propuesta nos planteamos los siguientes interrogantes: ¿cuáles fueron los elementos acusatorios que determinaron las sanciones hacia estas maestras y qué estrategia esgrimieron para su defensa? ¿De qué forma intervenían los inspectores escolares en los casos señalados, cuáles eran los procedimientos y qué estipulaba la reglamentación escolar?

Por un lado, nos interesa demostrar que en los tres casos la sexualidad, la moral y el género se instituyeron como códigos de control sostenidos por la burocracia educativa y que estos se extendían a la vida 
privada de las maestras, es decir, por fuera del espacio escolar. Estos tópicos irrumpen de manera transversal en las fuentes examinadas, otorgando novedad al acervo documental utilizado fundado en expedientes y actuaciones sumariales acopiadas en el Archivo Intermedio de la Nación (AIN). Por otro lado, entendemos que las denuncias o los comentarios que llevaron a cuestionar a las maestras ponían en tensión los valores que el magisterio fraguó sobre los pilares de un currículum escolar que justificada las diferencias de género, en donde varones y mujeres tenían roles culturalmente asignados. ${ }^{1}$

El trabajo dialoga con la historiografía que ha puesto de relieve la constitución de la moral y las costumbres para la interpretación de las relaciones entre los géneros, ${ }^{2}$ concibiendo el género como una categoría relacional, otorgándole una dimensión cultural más que biológica. ${ }^{3}$ También es tributario de la historia social del trabajo con perspectiva de género, ${ }^{4}$ que ha permitido reescribir e incorporar en la historia a un sector numeroso de la fuerza laboral que había sido invisibilizado por los investigadores/as. ${ }^{5}$

Nuestro enfoque se sostiene en aquellas producciones que enfatizaron en cómo las costumbres, las prácticas sociales y las normativas avalan actos entendidos como legítimos y otros como ilegítimos, que pugnan contra el modelo familiar tradicional en una época determinada. ${ }^{6}$

\footnotetext{
${ }^{1}$ La cultura normalista estuvo mediada por un currículum manifiesto y un currículum oculto. En líneas generales el currículum hace referencia a los elementos culturales del conocimiento, los valores, las costumbres, el régimen disciplinario, las creencias y la táctica escolar. Ver: Adriana Puiggrós, Sujetos, disciplina y currículum en los orígenes del sistema educativo (Buenos Aires: Galerna, 1990).

2 Dora Barrancos, Donna Guy y Adriana Valobra, Moralidades y comportamientos sexuales. Argentina, 1880-2011 (Buenos Aires: Biblos, 2014).

3 Joan Scott, Only Paradoxes to Offer. French Feminists and the Rights of Man (Cambridge: Harvard University Press: 1996).

${ }^{4}$ Mirta Lobato, Historia de las trabajadoras en la Argentina (1869-1960) (Buenos Aires: Edhasa, 2007); Valeria Pita, «De negociaciones cotidianas y de posibilidades históricas: una aproximación a los intercambios entre médicos y trabajadoras. Buenos Aires, 1870, 1940», Anuario de Historia Regional y de las fronteras 19, no. 2 (2014): 365-390; Graciela Queirolo, Mujeres en las oficinas. Trabajo, género y clase en el sector administrativo. Buenos Aires, 1910-1950 (Buenos Aires: Biblos, 2019); Karina Ramacciotti, «Profesiones sanitarias, género e historia», Avances del Cesor 13 (2016): 81-92.

${ }^{5}$ Andrea Andújar, «Historia social del trabajo y género en la Argentina del siglo XX: balance y perspectivas», Revista Electrónica de Fuentes y Archivos (REFA) 8, no. 8 (2017): 43-59.

${ }^{6}$ Isabella Cosse, Estigma de nacimiento. Peronismo y orden familiar, 1946-1955 (Buenos Aires: Fondo de Cultura Económica, 2006).
} 
También ponemos atención en los estudios sobre género que cotejaron la conformación y feminización del magisterio argentino ${ }^{7}$ y las autopercepciones forjadas por las maestras en relación con el género, la escuela y la ciudadanía; 8 la construcción de estereotipos sexuales en el sistema educativo y las sanciones disciplinarias o exoneraciones por inmoralidades. ${ }^{9}$ Particular atención merece el artículo de Paula Caldo (2019), ya que la historiadora analiza una de las fuentes citadas en esta pesquisa, aunque desde una perspectiva que tiene en cuenta cómo la escuela resolvió y sancionó el amor clandestino entre maestros/as. ${ }^{10}$ Por último, una vertiente de análisis interesante es la que ligó el perfil laboral del magisterio como una misión femenina, ${ }^{11}$ la educación de las estudiantes del magisterio como mujeres y como maestras durante el despegue de la sociedad de consumo en Argentina (1920-1930),12 y el entroncamiento del magisterio con las formulaciones católicas sobre el género femenino. ${ }^{13}$

La investigación se desprende de una naciente investigación que tiene como eje de análisis los conflictos entre escuelas y comunidades en los

\footnotetext{
${ }^{7}$ María José Billorou, «Mujeres que enseñan no solo en las aulas: docentes en el interior argentino en la primera mitad del siglo XX», Anuario de historia de la educación 17, no. 2 (2016): 57-79; Graciela Morgade, Mujeres en la educación: género y docencia en la Argentina: 1870-1930 (Buenos Aires: Miño y Dávila, 1997); Silvia Yannoulas, Educar, ¿una profesión de mujeres? La feminización del normalismo y la docencia (1870-1930) (Buenos Aires: Kapelusz, 1996).

${ }_{8}$ Marina Becerra, «Un prisma original: educación, género, amor y ciudadanía en Herminia Brumana», Anuario de Historia de la Educación 17, no. 2 (2016): 80-103.

9 Flavia Fiorucci, «Los amores de la maestra: sexualidad, moral y clase durante el peronismo», Secuencia 85 (2013). http://www.scielo.org.mx/scielo.php?script=sci_arttext\&pid=S0186-03482013000100003 (consultado el 15-12-2019).

10 Paula Caldo, «Entre amores clandestinos y cesantías. La maestra y el director, Argentina, 19201928», Géneros 26, no. 26 (2019): 145-163.

${ }_{11}$ Flavia Fiorucci, «País afeminado, proletario feminista. Mujeres inmorales e incapaces: la feminización del magisterio en disputa (1900-1920)», Anuario de Historia de la Educación 17, no. 2 (2016): 120-137. http://ppct.caicyt.gov.ar/index.php/anuario/article/view/9793 (consultado el 23-01-2019).

12 Paula Caldo, «No parecían mujeres, pero lo eran. La educación femenina de las maestras, Argentina, 1920-1930», Historia y sociedad 26 (2014): 237-265. http://www.scielo.org.co/scielo. php?pid=S012184172014000100010\&script=sci_abstract\&tlng=pt (consultado el 15-12-2019). Según la autora, en ese periodo la estética y el mercado operaron para generar la imagen de una maestra angelical, rígida, dulce y severa, una «segunda madre».

${ }_{13}$ Lucía Bracamontes, «Mujeres, trabajo y educación a principios del siglo XX: las maestras en la prensa católica del sudoeste bonaerense argentino», Diálogos, Revista Electrónica de Historia 12, no. 1 (2011): 101-127.
} 
territorios nacionales y provincias en las primeras décadas del siglo XX. ${ }^{14}$ Proponemos un trabajo exploratorio y para ello utilizamos un análisis descriptivo, desde una perspectiva cultural en clave de género, para ahondar en el campo de las sanciones institucionales, las representaciones y los mandatos de corte cultural reproducidos en el sistema escolar.

Hemos dividido el trabajo cronológicamente abrevando en las particularidades de cada caso, rastreando los fundamentos de las denuncias - $\mathrm{O}$ al menos, lo que sabemos- en boca de los directivos e inspectores. Cabe señalar que la extensión de los expedientes es dispar; por lo tanto, la descripción de cada caso queda sujeta a esta limitación y a las dinámicas particulares de este tipo de fuente en donde la información aparece parcelada o se omiten datos específicos. Por ejemplo, se habla de «inmoralidades» pero nunca se especifica qué tipo de faltas cometieron las maestras que atentaban contra ella.

Por añadidura, observamos que la moralidad fue uno de los pilares que sostuvo la cultura escolar como método de control sobre el personal docente y que se extendía por fuera del perímetro de la escuela a la vida privada de las mujeres y varones que habían escogido la enseñanza como profesión. ${ }^{15}$ La escuela sostuvo la construcción de un discurso que ligaba determinadas cuestiones éticas y morales con la división genérica de roles, un conjunto de ideas y representaciones preconcebidas sobre lo naturalmente femenino y lo masculino.

El corpus del artículo está dividido en cuatro estratos. El primero da cuenta del andamiaje normativo del CNE, el rol de los inspectores y la feminización del magisterio. El segundo analiza el caso de la maestra Paulina en Mendoza (1919); el tercero, el caso de Clorinda en Chubut (1921); y el cuarto, el caso de Dominga en Río Negro (1935). Por último, esbozamos una reflexión general a modo de conclusiones.

\footnotetext{
14 Los territorios nacionales fueron unidades administrativas centralizadas cuyo objetivo era consumar la expansión territorial luego de la sanción de la Constitución en 1853, delinear y controlar los espacios en disputa con los países limítrofes y fiscalizar a las comunidades indígenas que poblaban el terruño. Creados en 1884, abarcaban las actuales provincias de Chaco, Chubut, Formosa, La Pampa, Misiones, Neuquén, Río Negro, Santa Cruz y Tierra del Fuego.

15 Tomamos la definición de «cultura escolar» propuesta por Viñao Frago en cuanto a que estaría compuesta por un conjunto de teorías, ideas, principios, normas, rituales y prácticas que tienen continuidad y persistencia en el tiempo. Antonio Viñao Frago, Sistemas educativos, culturas escolares y reformas: continuidades y cambios (Madrid: Morata, 2002).
} 
El artículo puede aportar a los estudios de género, educación y trabajo , permitiéndonos rescatar las construcciones subjetivas y objetivas que subsumían a las mujeres en la lucha por la existencia cotidiana, batallando o naturalizando determinados arbitrios culturales que sostenía la tradición escolar y que hoy, en las primeras décadas del siglo XXI, se resisten a perecer en el sistema educativo.

\section{ALGUNAS CONSIDERACIONES SOBRE LA BUROCRACIA EDUCATIVA Y LA FEMINIZACIÓN DEL MAGISTERIO (PRINCIPIOS DEL SIGLO XX)}

El CNE se creó en 1881 con la misión de educar a la Nación. Junto con la Ley de Educación Común (ley 1420) de enseñanza libre, gratuita y laica de 1884, y la sanción de la Ley Laínez (1905), que le permitió al $\mathrm{CNE}$ crear escuelas en aquellas provincias que lo solicitasen al gobierno central, esencialmente por la falta de recursos; los funcionarios del CNE fueron una pieza fundamental para extender los servicios educativos tanto en las provincias como en los territorios nacionales. El CNE se transformó en una organización de alcance nacional con un equipo de funcionarios que debían velar por los intereses educativos, controlando los destinos de los recursos aportados por el gobierno central a las escuelas.

En 1890 el CNE impulsó el nacimiento de la Inspección de Escuelas Primarias en los territorios y colonias federales, a cargo del inspector Raúl Díaz quien se desempeñó en el cargo hasta 1916.16 Por su parte, el cuerpo de inspectores en las provincias federales estaba direccionado por la Inspección General de Provincias, a cargo de un inspector general y un subinspector. Contaba con cuatro inspectores viajeros, 14 inspectores seccionales y 75 inspectores visitadores. Estos funcionarios periódicamente elevaban los informes al CNE sobre la marcha de la educación en sus respectivas jurisdicciones. Los informes eran editorializados en el órgano de difusión del CNE: la revista El Monitor de la Educación Común. ${ }^{17}$

\footnotetext{
16 Díaz fue inspector entre 1890 y 1916. Sus prolíferos informes guiaron la política del CNE en los territorios nacionales y colonias, brindando un diagnóstico elocuente sobre la situación de la educación, los alcances y límites de la ley 1420.

17 Los funcionarios eran maestros formados en el normalismo y adherentes a la filosofía del positivismo. Bregaron por liderar la construcción profesional de la docencia. Este sector hizo señeros
} 
Como toda organización, la labor docente estaba normativizada por el Reglamento general de escuelas, sancionado a fines del siglo XIX con modificaciones posteriores. El Reglamento abarcaba un conjunto de aspectos ligadas con los mecanismos de selección, la administración escolar, la labor docente, la conducta y la moralidad del personal de las escuelas. Para ser maestro se debía justificar la capacidad técnica, moral y física para la enseñanza (artículo 44). Según el artículo 60 del capítulo III, los maestros debían cumplir estrictamente las disposiciones establecidas por las leyes, decretos y reglamentos escolares, asistir puntualmente a clases, observar las órdenes que los consejos escolares expedían sobre la administración de las escuelas y conservar el orden y la disciplina. ${ }^{18}$

Por su parte, el director estaba obligado, según el artículo 62, a cuidar el orden, la disciplina y la enseñanza, vigilar a los maestros/as, alumnos y empleados escolares y llevar un registro ordenado de las cuestiones administrativas. Tanto maestros como directores tenían prohibido recibir emolumento de los alumnos, padres y tutores, ejercer dentro de la escuela o fuera de ella cualquier oficio, profesión o comercio que los inhabilitase para cumplir con las obligaciones del magisterio; dar lecciones particulares a los alumnos de su escuela o imponer castigos corporales. La normativa se extendía a la prohibición de hacer propaganda en favor o en contra de creencias políticas o religiosas.

Con respecto a los derechos de los maestros, el Reglamento estipulaba que eran inamovibles; sin embargo, su estabilidad peligraba ante enfermedades que pusieran en peligro la salud de los niños/as, conducta inmoral o delictuosa, o abandono injustificable de sus tareas.

Para llevar adelante los procesos investigativos en caso de denuncias o faltas consideradas graves, según la óptica de la superioridad, estos funcionarios se regían por la Comisión de Sumarios. En 1925 se presentó un nuevo proyecto direccionado por dicha Comisión, que dio a luz al

esfuerzos para alcanzar el monopolio de la actividad. Con tal propósito surgieron asociaciones que trataron de mejorar las condiciones de todos los estamentos docentes. Ver: Ricardo González Leandri, «La elite profesional docente como fracción intelectual subordinada. Argentina: 1852-1900», Anuario de Estudios Americanos 58, no 2, (2001): 526.http://estudiosamericanos.revistas.csic.es/index.php/estudiosamericanos/article/view/214 (consultado el 12-03-2019).

18 Reglamento general de escuelas (Buenos Aires: CNE, 1900). 
Reglamento de sumarios. Con esto se buscaba agilizar los trámites que muchas veces se dilataban y aplicar, en términos precisos, las sanciones punitivas a los remisos. En rigor, con el nuevo Reglamento se reducía el término total para substanciar un sumario a 70 días. Aprobado recién en 1927, las denuncias debían ser orales o escritas, y podían ser presentadas ante las direcciones de las escuelas, las inspecciones seccionales de provincias y territorios, o en la Mesa de Entrada del CNE. Los sumarios podían ser realizados de oficio, por denuncia o por prevención. Los causales abarcaban las siguientes situaciones: conducta delictuosa, desarreglada o inmoral, negligencia en el cumplimiento de las obligaciones del cargo que se ocupase; falsedades o inexactitudes en los datos consignados en los documentos. También contemplaba la incapacidad para el mantenimiento y el orden, entre otras.

El sumario debía ser escrito y secreto y el inspector sumariante estaba obligado a citar a los denunciantes, consignar los datos personales e interrogarlos con preguntas muy precisas. El proceso sumarial incluía la citación del denunciante, del acusado y de testigos, la presentación de pruebas y defensa y el dictamen del Consejo Escolar. La Comisión de Asuntos Legales y la Asesoría Letrada eran las encargadas de estudiar los casos y emitir juicio sobre la necesidad de sanciones legales o la absolución del denunciado. ${ }^{19}$

Esta breve descripción del armado institucional les permitía a los inspectores transitar por los lugares más apartados del terruño, responder a las demandas de las comunidades locales cuando solicitaban la creación de una escuela o intervenir ante los conflictos suscitados entre el personal docente y los vecinos. La agreste geografía que debían recorrer demandaba funcionarios capaces de sortear todo tipo de obstáculos en los trayectos asignados. A la diseminación de la población en los territorios nacionales y en las escuelas rurales de las provincias y la falta de caminos aptos para el tránsito, se sumaba la disparidad cultural de las comunidades locales, criollas o indígenas, que en ocasiones miraban con desconfianza a los maestros/as. ${ }^{20}$

\footnotetext{
${ }_{19}$ Reglamento de sumarios (Buenos Aires: CNE, 1927).

${ }^{20}$ Adrián Cammarota, «Nacionalizar y educar: algunos problemas de la educación común en los territorios nacionales (1890-1940)», Avances del Cesor (2019) (en prensa).
} 
Ahora bien, los impedimentos para llevar los servicios educativos al grueso del territorio nacional eran materia de discusión por parte de los funcionarios. Por ejemplo, en 1911 en la reunión anual de inspectores de territorios nacionales se debatía sobre la falta de idoneidad de los maestros/as, el ausentismo y la moralidad del personal docente. Pero también se percibía un proceso que para algunos funcionarios era perjudicial para la educación primaria: la feminización del magisterio. Por ejemplo, el inspector de territorios nacionales Marcelino Martínez observaba sobre la necesidad de que las escuelas públicas estuviesen «impregnadas de un espíritu viril, y de ahí que es menester formar al maestro varón y atraerlo, dándole alicientes é individualidad, tal cual ocurre con los militares y el clero». Para el funcionario, la feminización del magisterio estaba devaluando la función republicana de la escuela. ${ }^{21}$ Desde otro ángulo, no podemos obviar que la burocracia educativa del CNE durante las primeras décadas del siglo XX era netamente masculina. ${ }^{22}$

Hay que señalar que a principios del siglo XX las mujeres realizaban trabajos domésticos, administrativo ${ }^{23} \mathrm{O}$ se concentraban en las fábricas, donde la producción estandarizada las convirtió en trabajadoras en el ámbito urbano, atentando contra el supuesto rol maternal que debían expresar. Por su parte, el magisterio se transformó en una profesión femenina ya que ser maestra, en el imaginario social, representaba la extensión hogareña del rol maternal y también les permitía tener una profesión. ${ }^{24}$

La descripción precedente sobre el deber de los funcionarios, el reglamento y la feminización del magisterio nos permite entrever los casos de las maestras que se vieron denunciadas. A continuación se realizará un análisis en orden cronológico, abrevando en los tópicos e indicios más relevantes que, a nuestro criterio, emergen de las fuentes consultadas.

\footnotetext{
21 AIN, Caja 89. Fondo: CNE, 1911.

22 Un dato sustancial brinda asidero a esta observación: entre 1881, año de la creación del CNE y el año 1933, por tomar una muestra estadística, de 133 funcionarios que ocuparon cargos en la repartición central tan solo cuatro fueron mujeres: Trinidad Osuna, Elvira Dellepiane, Carmen S. de Paudolfini e Inés Recalt, vocal del 4 de mayo de 1932 al 19 de noviembre de 1932 (CNE, tomo II, 1938: 3-5).

23 Ver: Queirolo, Mujeres en las oficinas.

${ }^{24}$ Marcela Nari, Políticas de maternidad y maternalismo político. Buenos Aires, 1890-1940 (Buenos Aires: Biblos, 2004).
} 


\section{9, MENDOZA. CASO PAULINA: LA MAESTRA DE DUDOSA MORALIDAD QUE VIAJABA}

Rosario de Q., Paulina del Rosario Q., Rosario Q. G. Así firmaba la maestra de 21 años, nacida en San Luis en 1889, quien se desempeñaba como auxiliar desde el 23 de julio de 1918 en la escuela nacional N. ${ }^{\circ} 16$ en Villa Rivadavia (provincia de Mendoza), con el título de maestra normal. En 1884 el departamento Rivadavia se había creado por la legislatura de Mendoza y, en 1900, se transformó en la cabecera del departamento. Esta escuela se fundó con el objetivo de alfabetizar a los niños/as que habitaban en la localidad.

Como telón de fondo, el año 1919 había sido espinoso para el gobierno provincial que estaba en manos del caudillo Néstor Lencinas, alineado con el presidente radical Hipólito Yrigoyen (1916-1922). Ante la precaria situación laboral de los maestros/as, la provincia fue testigo de una gran huelga que llevó al director general de Escuelas a separar a la maestra mendocina Florencia Fossatti (1888-1978), quien junto a la docente Angélica Mendoza (1889-1960) fundó el boletín Ideas, cuyo objetivo era organizar a los maestros/as. Siendo suspendidas por incitación a la anarquía, fundaron un gremio, Maestros Unidos, y promovieron una huelga general que se extendió a toda la provincia y fue reprimida por la policía. ${ }^{25} \mathrm{El}$ accionar de estas mujeres ponía en tensión los valores patriarcales, éticos y morales, sostenidos por el poder político local, el magisterio y la Iglesia que, como era de esperarse, se pronunció contra estas mujeres. El caso no sería una excepción, ya que el rol político que fueron adquiriendo las mujeres en el campo del magisterio, defendiendo las condiciones laborales, generando agencia y resquebrajando los estereotipos de género que las subsumía al valor de la abnegación y a un espacio de dependencia respecto del varón; puede vislumbrarse en el estudio sobre la huelga docente en Firmat, en 1921 en la provincia de Santa Fe, iniciada por la falta de pagos de los salarios. ${ }^{26}$

\footnotetext{
${ }_{25}$ Ver: Rodolfo Richard Jorba, «Somos el Pueblo y la Patria. El populismo lencinista en Mendoza frente al conflicto social y la prensa: discursos, representaciones y acciones, 1917-1919», Revista de Historia Americana y Argentina 48, no. 1 (2013): 11-54.

${ }^{26}$ Micaela Pellegrini, «Huelgas, maestras y rumores. Una escena de mujeres en lucha a partir de un estudio de caso (FIRMAT, Argentina, 1921)», La Ventana 49 (2018): 283-316.
} 
A juzgar por el expediente, Paulina no había participado de la huelga provincial de 1919 en Mendoza. Sin embargo, comenzó a notar que tanto la directora como el encargado escolar de la escuela N. ${ }^{\circ} 16$ se hicieron eco de ciertos comentarios que circulaban en el vecindario sobre su vida privada. ${ }^{27}$ A ello se sumaba el concepto profesional que, según las autoridades, era el peor. En nota al visitador de escuelas nacionales, el encargado escolar también dejó a las claras que:

Desde el principio la moralidad de la señorita Q. me pareció sospechosa, con el tiempo me la ha confirmado en las irregularidades de sus actos morales, un cierto lujo que ha gastado me parece que no está en armonía con su situación pecuniaria aparente, tanto más que invoca a menudo su pobreza a causa de tener una madre y una hermana enferma (...) Muchas ausencias y viajes en los días libres de escuela no abonan en favor de la economía que debería ser forzosa para ella.

Esta señorita gusta mucho de moverse afuera de su casa y eso no es ciertamente para perfeccionarse en pedagogía. Por otra parte, circulan rumores que no sé hasta qué punto pueden ser ciertos que su moralidad no goza de buena fama en el vecindario. ${ }^{28}$

No solo la moralidad de Paulina levantaba sospechas. Los pedidos de licencia por enfermedad y su ausencia de la escuela parecían reforzar ese argumento. Por ejemplo, el 12 de febrero de 1919 Paulina solicitó una licencia médica a la directora de la escuela Esmeralda Q. hasta el 1 de marzo, ya que se encontraba convaleciente de «una terrible enfermedad que la había postrado en la cama». También debía cuidar a su hermana que estaba en gravísimo estado de salud, lo cual no le permitía levantarse. ${ }^{29}$

Hay que señalar que la salud de los maestras/as era una de las preocupaciones de los servicios médicos escolares, ya que en los edificios era frecuente la transmisión de enfermedades. En el mes de julio, Paulina

\footnotetext{
27 Los encargados escolares cumplían funciones netamente administrativas.

28 Nota del encargado escolar al visitador de escuelas, 28 de agosto de 1919. AIN, Caja 3, 1921. Fondo: CNE.

29 Según el artículo 74 del Reglamento, las licencias solicitadas por los docentes debían hacerse por escrito con la comprobación de los causales con certificado médico.
} 
volvió a pedir licencia a la directora debido a una conjuntivitis granulosa que la tenía a mal traer. Luego solicitó extender la licencia un mes más, ya que la enfermedad no había sido erradicada de su organismo. ${ }^{30}$ Pero las sospechas de la directora y el encargado escolar abrevaban también en otras causales.

No sabemos cómo fue obtenida, pero en el expediente hay una nota personal de la maestra dirigida a un hombre donde describe su situación. La carta está escrita en un tono coloquial y bosqueja una pincelada de su intimidad:

Fíjate en lo que te escribo [...] Cómo te va y si ya te mejoraste y paso el sueño y la curda poco oportuna [...] Yo regular, estoy bastante enfermita y ayer pase un día pésimo, pero no habrá que dudarlo. Llegué a buena hora para entrar a clase pero no tenía voluntad de trabajar. Dime negro, cómo sigue la nena, créeme que eso me inquieta demasiado y no me deja un instante su pensamiento. Como tú eres tan bueno, habrás ido a verla anoche y hoy también, y le habrás dado los masajes, ¿no? Por favor, no me la abandones mientras yo no estoy. Solo el mal cuidado la tiene enferma. Cuando vaya te contaré muchas cosas. Ahora me concreto a decirte que sigo mal y peor de mi garganta [...] La Estelita está muy linda, no extraña nada [...] unos besitos y unas miraditas con sus ojasos (sic) negros [...] Si no te fuera una molestia, el viernes en la noche la vengas a ver a la nena [...] Y sino ya sabes que iré el sábado, ¿no? [...] procura que a la Clarita no le falte nada y que le pongan vaselina en la boquita y en la nariz, constantemente para que sane. Te besa con cariño tu negra Rosario [Paulina].

Hoy 7 de mayo a las $10 \mathrm{am}^{31}$ (1919).

Era evidente que la carta había reforzado la sospecha del personal escolar, junto con los pedidos de licencia y la identidad de su hija. Con respecto a esto último, unos meses antes, el 24 de febrero de 1919, Paulina se había presentado en el Registro Civil de Villa Rivadavia acompañada por dos vecinos de la localidad, Pedro L. y Ramón O., presentando

\footnotetext{
${ }^{30}$ Rodríguez Peña, 19 de junio de 1919. AIN, Caja 3, 1921. Fondo: CNE.

${ }_{31}$ AIN, Caja 3, 1921. Fondo: CNE.
} 
a su hija natural, Clara Rosa Q., con la idea de verificar su identidad. La utilización de diversas firmas por parte de Paulina había generado confusión y sospechas en la escuela. Se comprobó que el acta de nacimiento de su hija la había firmado como Rosario Q. Por lo tanto, la directora y el inspector habían solicitado validar la identidad de la maestra en el Registro Civil.

Siguiendo el procedimiento sumarial estipulado por el reglamento, el 17 de noviembre de 1919, el inspector interrogó a Paulina. Allí testificó que habitaba con su madre y una hermana inválida, una sobrina de cuatro años (Estela) y su hija Clara Rosa, de seis meses. Ante la pregunta por la variedad de firmas utilizadas, la maestra respondió que no le agradaba el nombre Paulina y que prefería el de Rosario. A veces al apellido Q. le agregaba el apellido materno, G. La pesquisa continuó haciendo un racconto de los comentarios, características de la unidad familiar y la filiación de la hija de Paulina. ${ }^{32}$

El funcionario preguntó en qué localidad había pasado la vacación del último curso escolar, a lo que la joven respondió: «En el departamento de San Martín y un tiempo en la ciudad». Luego él inquirió: "¿Qué razones hay para alejarse con tanta frecuencia de la localidad de asiento y de la escuela, teniendo en ella a su madre?». Paulina esgrimió que tenía asuntos de familia que otra persona no podía desempeñar, por lo que ella se había visto obligada a hacerlo personalmente. A continuación, el funcionario invocó uno de los temas más espinosos: «¿Quién es el padre de la niñita, Clara Rosa y dónde vive?». Paulina alegó que no era indispensable nombrarlo, por lo tanto, se abstenía de hacerlo, lo mismo que su domicilio. Su declaración no alcanzó para convencer al funcionario sobre los puntos sensibles del interrogatorio. ${ }^{33}$

Paulina del Rosario Q. G. fue suspendida por la Inspección Seccional el 11 de septiembre de 1919 «por estar su conducta reñida con las prácticas de las buenas costumbres y observar moralidad en abierta contradicción con la que el puesto exige...». ${ }^{34}$ Ella se defendió en nota al inspector

\footnotetext{
32 La fuente no aclaraba el contenido de esos comentarios.

33 Visitador escolar Roberts. 17 de noviembre de 1919. AIN, Caja 3, 1921. Fondo: CNE.

34 Mendoza, Inspección Seccional 11 de septiembre de 1919. AIN, Caja 3, 1921. Fondo: CNE.
} 
general de provincias del CNE aludiendo a que la señora directora y el encargado escolar cometían una serie de injusticias contra ella,

sin que jamás haya merecido de mis superiores observación ni apercibimiento alguno y habiendo soportado hasta el exceso las tiranteces y las injusticias de la Sra. Directora, hasta el extremo de no dejarme la libertad necesaria a un maestro para desempeñar sus funciones, hasta el extremo de haber sido tratada de anarquista procurando hacerme perder el ascendiente moral que todo maestro debe tener frente a sus alumnos [....$^{35}$

Con respecto a la acusación de anarquista, esta comportaba una connotación negativa, pasible de sanciones del orden disciplinario o la exoneración. La escuela, a fines del siglo XIX, se había constituido sobre los pilares del nacionalismo que pretendía homogeneizar a una población que, producto de la inmigración, la llegada de ideologías foráneas como el socialismo y el anarquismo, y la protesta social, ponía límites a los intentos de homogeneización cultural. ${ }^{36} \mathrm{Y}$ de más está decir que las sensibilidades de la jerarquía escolar estaban tocadas por la huelga docente de 1919.

Paulina dejó de prestar servicios el 12 de septiembre de 1919, conforme a lo expresado por la Inspección General de Provincias, quien requirió su cesantía. Ahora bien, ¿qué indicios o conjeturas nos permiten distinguir las causas que llevaron a su sanción más allá de la acusación que pesaba sobre la maestra?

\section{CONJETURAS Y SUMARIO}

Como hemos señalado, acorde a la Comisión de Sumarios del CNE, las denuncias debían ser orales u escritas y podían ser presentadas ante las direcciones de las escuelas, las inspecciones seccionales de provincias y territorios, o en la Mesa de Entrada del CNE en la Capital Federal.

\footnotetext{
35 Como parte del control de la burocracia educativa, anualmente los docentes eran evaluados por sus superiores, con base en su desempeño, capacidades técnicas y predisposición al trabajo. 18 de septiembre de 1919, AIN, Caja 3, 1921. Fondo: CNE.

${ }^{36}$ Lilia Bertoni, Patriotas, cosmopolitas y nacionalistas. La construcción de la nacionalidad argentina a fines del siglo XIX (Buenos Aires: Fondo de Cultura Económica: 2001).
} 
Paulina no tuvo denunciantes concretos en el pueblo ni en la escuela, o al menos no aparece en el expediente la denuncia en cuestión. Las sospechas sobre su conducta partieron de la dirección escolar y fueron apoyadas solo en comentarios o rumores infundados que, según el reglamento, no debían ser motivo de sanciones. El rumor implica una aseveración sin pruebas existentes, está caracterizado por su ambigüedad y por la ausencia de detalles específicos. Posee una fuerte carga emocional y una asimilación a la expectación, es decir que muchos detalles adquieren una forma destinada a apuntalar los hábitos mentales inveterados por los interesados. A medida que el rumor se expande, este se vuelve más conciso y compacto, lo que le permite fluir con rapidez. ${ }^{37}$

También podemos conjeturar que uno de los puntos sensibles era la filiación de su hija Clara. ¿Podía ser que los comentarios de los vecinos se nuclearon en torno a una representación que asociaba las posibilidades de una hija ilegítima con los desbordes sexuales de la maestra que se ausentaba de su domicilio? Dada la época, las mujeres solteras, viudas o con hijos cuyos padres no les daban el apellido y bajo sospecha de mantener relaciones sexuales eran consideradas generalmente como inmorales. Durante mucho tiempo la moralidad estuvo asociada a la indiscreción de naturaleza sexual.

De esta forma, un punto de partida para comprender el caso señalado es ver cómo este estaba riñendo con el modelo jurídico de la época a pesar de los cambios acaecidos a mediados de la década de 1920. El Código Civil sancionado en 1869 consideraba a la mujer como una menor de edad. Aunque no fueron pocas las voces femeninas que se levantaron a principios del siglo XX contra él, jurídicamente la mujer casada quedaba bajo la tutela del marido, ya que el artículo 55 sostenía la incapacidad relativa de la mujer y encargaba al esposo como el administrador de todos los bienes. Recién en 1924 se reformó el Código Civil y se sancionó la igualdad de los sexos bajo cualquier estado conyugal.

Queda a las claras que Paulina transgredía esas miradas al trasladarse de una localidad a otra, siendo maestra, madre soltera y con una hija pequeña sin apellido paterno. Y es que Paulina, como el resto de las mujeres de este trabajo, fueron moldeadas según las convenciones sociales

\footnotetext{
37 Gordon Allport y Leo Postman, Psicología del rumor (Buenos Aires: Editorial Psique, 1973).
} 
que pautaban conductas y deberes: las mujeres decentes no podían trasladarse sin compañía u hospedarse sola en los hoteles, debían estar custodiadas por el marido o por algún familiar cercano, como un hermano. 38

¿Era ilegítima la hija de Paulina? Pues bien, con respecto a este último punto hay que señalar que la ausencia del apellido paterno era una suerte de desdicha social. El número de hijos ilegítimos en la Argentina preocupaba a la elite dirigente ya que, entre otras cosas, atentaba contra el ideal familiar, generando una sociedad disfuncional. ${ }^{39}$

\section{MODELO FAMILIAR E ILEGITIMIDAD}

Los viajes de Paulina, los comentarios y la ausencia de apellido de su hija también pugnaban con el modelo familiarizante expresado en la cultura escolar. Con la ampliación de los poderes del Estado sobre el territorio nacional y la modernización, emergió un modelo familiar que se institucionalizó como ejemplo a seguir en todos los sectores sociales y cuyo ideal de domesticidad fue decantando de los discursos escolares, la religión católica, las ideas de las elites y el discurso médico. ${ }^{40} \mathrm{El}$ ideal de domesticidad, entendido como el matrimonio legítimo, el modelo de familia nuclear, la descendencia conyugal y la diferencia de roles entre varones y mujeres había alcanzado su máxima expresión durante esa época.

Este ideal se encarnizaba en las imágenes y las representaciones explicitadas en el currículum escolar. La maestra esbozada en los discursos y en los textos escolares transfiguraba un nudo de sentidos que se asumían como inmutables por parte de la burocracia educativa. Individualizados

\footnotetext{
${ }^{38}$ Sin embargo, como ha señalado Barrancos, desde la década de 1920 comienza a vislumbrarse en los grandes centros urbanos una nueva moralidad sexual en las trabajadoras. Dora Barrancos, «Moral sexual, sexualidad y mujeres trabajadoras en el período de entreguerras», en Historia de la vida privada en la Argentina. Tomo 3: La Argentina entre multitudes y soledades. De los años 30 a la actualidad, dirs. Fernando Devoto y Marta Madero (Buenos Aires: Taurus, 1999), 199-225.

${ }^{39}$ Desde 1910 se había transformado en un problema de agenda estatal. De cada mil niños nacidos vivos en 1910, 220 de ellos eran ilegítimos en el conjunto del país. En 1938 la cifra trepó a 282. Alejandro Bunge, Una nueva Argentina (Buenos Aires: Hyspamerica, 1984 [1940]), 173.

40 Enrique Míguez, «Familias de clase media: la formación de un modelo», en Historia de la clase media en la Argentina. Tomo 2: La Argentina plural (1870-1930), dirs. Fernando Devoto y Marta Madero (Buenos Aires: Taurus, 2010), 21-45.
} 
sus cuerpos, carentes de insinuaciones o sexualidad, estas no podían despertar suspicacias en torno a sus comportamientos. Otro ejemplo presente en los textos escolares de época es que eran pocas las mujeres que participaban del mercado laboral, a diferencia de los varones. Estaban empleadas en un espectro de ocupaciones que abarcaba hasta 30 actividades, concentrado en los servicios personales y la docencia. El de los varones se ampliaba a 156, cuyas ocupaciones abarcaban desde artesanos hasta ministro de Hacienda. En los textos del ciclo primario, los niños/as tenían padre y madre y nombre y apellido, lo cual afianzaba la imagen ideal de la familia. Estas representaciones no se modificaron hasta la década de $1980 .{ }^{41}$

La esfera social, ámbito donde se destaca la escuela pública, espera de cada uno de sus miembros un cierto tipo de comportamiento, que tiende a «normalizar» las conductas de sus miembros. ${ }^{42}$ Esta concordancia entre la esfera pública y la esfera privada nos invita a pensar el caso de Paulina, y los intersticios genéricos y culturales que pautaban y condicionaban los comportamientos socialmente aceptables.

\section{1, CHUBUT. CASO CLORINDA: LA MAESTRA ACOSADA Y EL DIRECTOR ENAMORADO}

A principios del siglo XX un 40\% de la población de Chubut vivía en agrupaciones urbanas, mientras que el $60 \%$ era población rural. Las primeras escuelas en la provincia de Chubut datan con anterioridad a la sanción de la ley 1420 de Educación Común. Por ejemplo, en 1878 se fundó la Escuela Mixta de Rawson. El 6 de abril de 1905 la escuela N. ${ }^{\circ}$ 24 de Comodoro Rivadavia había nacido, como muchas de las escuelas en los territorios y provincias, gracias a las demandas de los vecinos. La localidad, cuya actividad primaria era el petróleo, se creó el 23 de febrero de 1901 por decreto del gobierno nacional. A partir de 1907 se empezó a explotar el petróleo, lo cual dio como resultado un incipiente crecimiento poblacional.

\footnotetext{
${ }^{41}$ Catalina Wainerman, «Mujeres que trabajan. Hechos e ideas», en Población y bienestar en la Argentina del primero al segundo centenario. Una historia social del siglo $X X$, comp. Susana Torrado (Buenos Aires: Edhasa, 2007), 327-352.

42 Silvia Yannoulas, "Acerca de cómo las mujeres llegaron a ser maestros (América Latina, 18701930)», Rev. Bras. Estud. Pedagog. 73, no. 175 (1992): 504.
} 
En 1905 los inspectores del CNE visitaron la ciudad y dieron su aval para la radicación de la institución. El maestro I. Q. fue elegido como director, a pesar de que no poseía título profesional. Se trasladó desde La Pampa junto con su esposa que también era maestra. El director también oficiaba como electricista, carpintero y albañil. Muchos de los chicos que concurrían bajaban de la cordillera y eran mestizos e indígenas, lo que obligó a Q. a crear una suerte de internado, y era su mujer quien se ocupaba de la cocina y del cuidado de los niños/as.

El maestro había tenido una gran labor en la comunidad. En 1911 imprimió el primer periódico quincenal titulado El infantil, donde se publicaban los trabajos de los alumnos/as, noticias escolares y locales. Mientras tanto, la matrícula de la escuela crecía gracias a la llegada de nuevas familias de trabajadores/as.

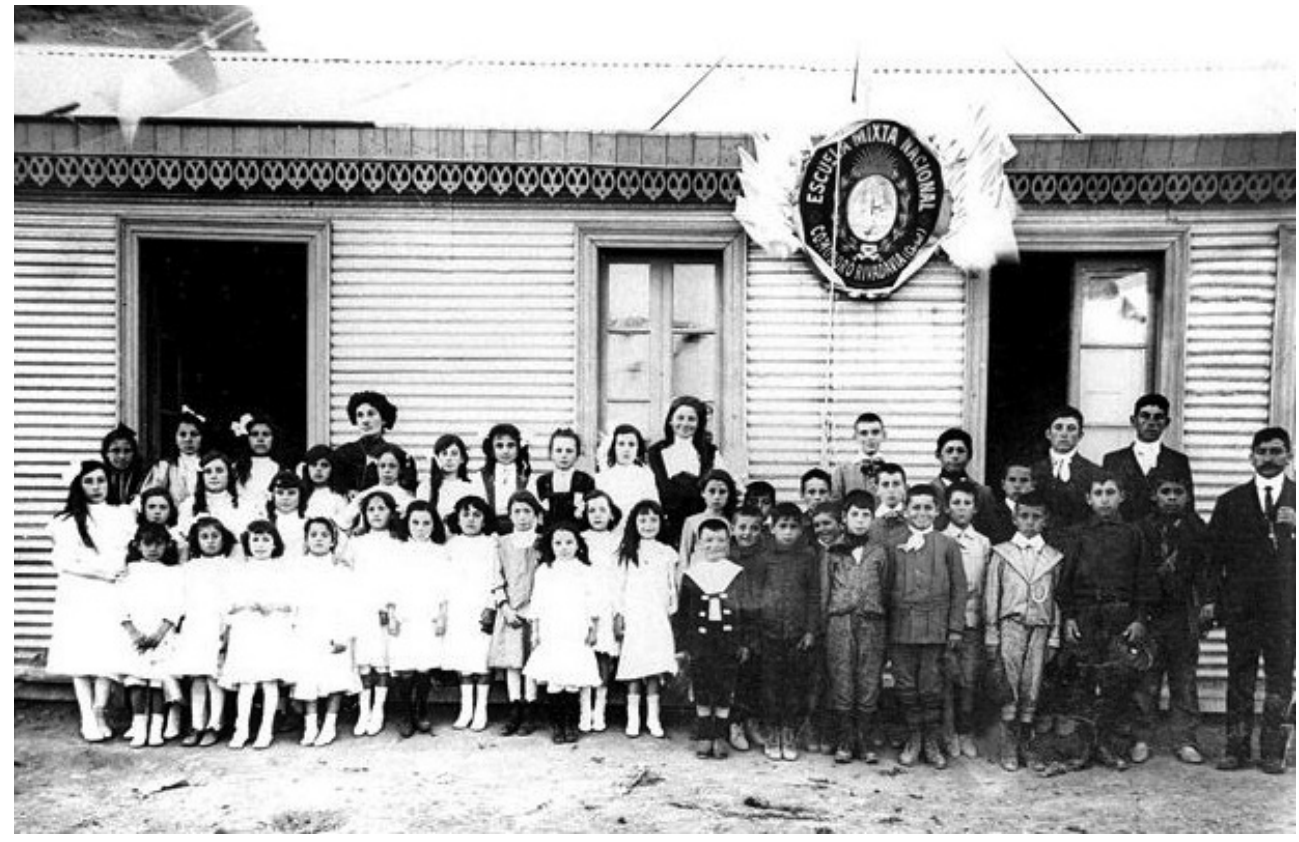

Escuela N. ${ }^{\circ} 24$ (Chubut) a principios del siglo XX. Fuente: El Patagónico, https://www. elpatagonico.com/la-escuela-83-tiene-el-orgullo-ser-la-mas-antigua-comodoro-n615859

En 1921 Clorinda M. era una de las maestras de la escuela N. ${ }^{\circ} 24$ (imagen). Tenía 30 años, no estaba casada, profesaba 17 años de antigüedad en la docencia y era maestra de tercera categoría sin título habilitante. 
Había trabajado en escuelas Laínez de San Luis, La Pampa, Neuquén y Chubut. Fuera de su actuación profesional, cuidaba a su madre enferma en un cuarto de hotel y tenía un hermano, Leonardo M., también docente. La vida de Clorinda se reducía a este círculo. Trabajo y familia distraían su atención y postergaban su desposamiento y maternidad. Sin embargo, Clorinda comenzó a percibir que en la escuela, el reconocido director Q., de 47 años, predicaba una relación que iba más allá de lo laboral. La carta que sigue atestiguaba estas intenciones:

Que no te puedo mirar;

Sin sentir dentro de mí;

Con delirio y frenesí

Mi corazón palpitar

Los modestos versos que anteceden reflejan toda una verdad, pues cuando tengo la dicha de verla y contemplarla, experimento emociones grandes que me llevan al extremo de forjarme ilusiones halagüeñas. ¡Ya se imaginaría usted cuáles serán esas ilusiones! Le estoy íntimamente agradecido a las exquisitas atenciones y deferencias que me ha dispensado.

Cada vez que recuerdo los besos que le he dado, y el toque de piernita, como el de su también linda papadita, me entusiasmo de forma tal que Ud. no se puede imaginar. Bien debe comprender mi querida, que no es necesidad de mujer, la que me hace hablar sino un amor de verdad el que es el que le profeso. Si Ud. me correspondiese entonces verá lo bien que sé amar (...).

$¡ A$ Ah! La respuesta me la da verbal o bien por escrito, pero entregándomela personalmente.

La besa y abraza,

Q. ${ }^{43}$

Una lectura descontextualizada de la carta entrañaría una situación de cortejo sentimental propio de la época, adecuado al intercambio epistolar entre dos amantes y presente en las novelas románticas que

${ }^{43}$ AIN, Caja 3. Fondo: CNE, 1921. 
insinuaban pasiones y deseos. Según Roxana Pagés, las cartas constituyen geografías discursivas que nos permiten acercarnos al saber y decir del momento histórico en el que se fragua la individualidad. Son documentos no mediatizados, ya que no fueron concebidos con una intención artística de ser publicados. ${ }^{44}$ Por su parte, la investigadora Paula Caldo (2019) ha enfatizado para esta fuente que la escritura epistolar suele capturar huellas tangibles de las experiencias sensibles. Las frases esgrimidas por el superior dejen entrever una petición de permisos con miras a profundizar en la relación amatoria. Así las cosas, el discurso del varón que desea un encuentro sexual se halla matizado con formulaciones románticas. ${ }^{45}$ Sin embargo, la carta no generó lo que el director podía haber especulado en su fuero íntimo.

El hermano de la maestra lo denunció al inspector general de escuelas y territorios nacionales, apuntando a las situaciones de acoso del director ejercidas sobre su hermana, con comentarios y propuestas amorosas indecorosas. Esgrimía que el director era un «alcolista consuetudinario» (sic) y que en tal estado se presentaba ante la maestra, atentando contra la moralidad. Según el hermano, «la moralidad de mi hermana, después de 11 años de labor docente en las escuelas Laínez, es reconocida por los inspectores e igualmente por la población del lugar». Así, en vez de recibir «estímulos sanos» y comprensión en la escuela por la enfermedad de su madre, el director, "con sus instintos de reptil y su espíritu pestilente, quiere contaminar a las personas honestas y sanas de alma».46

Clorinda no se animó a denunciar. Quizás pensó que su hermano, siendo la figura masculina, estaba habilitado para defender la afrenta contra su persona. Podemos hipotetizar sobre el frágil entorno emocional de Clorinda, que ayudaba a su madre convaleciente y tenía una endeble situación material. Tal vez, Clorinda juzgó que los vecinos pensarían que era una joven maestra despechada tras una aventura amorosa con el director.

\footnotetext{
${ }^{44}$ Roxana Pagés-Rangel, Del dominio público: Itinerarios de la carta privada (Ámsterdam-Atlanta: Rodopi, 1997), 45.

${ }^{45}$ Caldo, «Entre amores clandestinos y cesantías», 148-149.

4612 de enero de 1921. AIN, Caja 3. Fondo: CNE, 1921, folios 2-3.
} 
Transcurridos cuatro meses de la denuncia, la causa continuaba sin novedades. Decepcionada por la inercia burocrática, la maestra decidió escribirle al inspector de escuelas de territorios y colonias nacionales, Lorenzo Lucena. Allí insistía en que el director la había acosado primero con groseras insinuaciones, luego con actitudes poco caballerescas y, por último, con una carta de su puño y letra.

\section{LA DEFENSA DEL DIRECTOR}

Como era de esperar, el director realizó su descargo en un escrito dirigido al inspector escolar, Arturo Roberts. Negó su alcoholismo aludiendo a que solo en su modesta mesa solía tomar vino o cerveza. Insinuó que solo en contadas ocasiones concurría a la confitería, pero por invitación de personal de «alta cultura, moral y social», a tomar una taza de té o una copa de licor. Por lo visto, el director gozaba de una vasta red de relaciones en la sociedad local. ${ }^{47}$

Como era costumbre en estos casos, el denunciado ofrecía testimonios de honorabilidad: el vecindario de Comodoro Rivadavia, la Comisión Directiva, la Asociación Nacional de Boy Scouts Argentinos y la Explotación Nacional de Petróleo, de la que era su secretario. Más problemático era para el director la carta, de la cual no desconocía su autoría. «Todas las inmoralidades son verídicas», dice Q., «sin embargo, han tenido lugar en la habitación de hotel que la señorita M. ocupara con su madre enferma»:

Fuera de ese cuarto no han salido ni se han traslucido las relaciones impúdicas que la señorita M. me brindara con sus incitaciones. Jamás imaginé que la señorita $\mathrm{M}$. iba a iniciar un juicio sobre las insanas relaciones, por cuanto ella misma fue la promotora y supo aceptar esas acciones con frecuencia y en una manera tal que el mismo declarante se ruborizaba y dudaba de la pulcritud de la señorita M.48

Según Q., apenas él entraba en el alojamiento, «la maestra cerraba la puerta y empezaba con galanterías y obscenidades». La señorita M.

\footnotetext{
${ }^{47}$ AIN, Caja 3. Fondo: CNE, 1921, folio 19.

${ }^{48}$ AIN, Caja 3. Fondo: CNE, 1921, folio 20.
} 
quizás llegó a esas instancias, debido a los «impulsos propios de solterona treintanaria o por sobornarme a fin que sus deficiencias docentes pasaran desapercibidas por el director». ${ }^{49}$

Clorinda ratificó su denuncia aludiendo a que no podía citar testigos debido a que los hechos habían ocurrido en su habitación de hotel. Las únicas personas a las que podía interpelar eran aquellas que atestiguaban sobre su condición de mujer honesta, miembros de la sociedad de Villa Rivadavia.

\section{DEBILIDAD FEMENINA Y ULTRAJE DE LOS VALORES PROMOVIDOS POR LA CULTURA ESCOLAR}

Para la maestra, la actitud del director ultrajaba una serie de valores sostenidos en la cultura escolar: padre de numerosos hijos, había hecho tabla rasa con su cargo y con su situación dentro de la sociedad y la familia, "para lanzarse, perennemente alcoholizado, a cometer actos que repugnan a los más delicados sentimientos y a los más elevados conceptos de hombría y caballerosidad, actos que son una ofensa a todas las familias de Comodoro Rivadavia».50 Asimismo, quedaba claro que la denunciante se sentía en condición desigual por su sexo: «En mi debilidad femenina he confiado el caso a una familia de aquí y tan grande ha sido la indignación de los jefes de la misma que pensaron hacer una campaña periodística contra la Dirección de la escuela».51

El pensamiento de la maestra traslucía la internalización de los discursos proyectados por distintos actores y disciplinas, como la medicina diplomada, que centraba su atención en la diferenciación entre mujeres y varones y las justificaciones seudocientíficas positivistas de fines del siglo XIX. Estos, en nombre de la anatomía y la fisiología, feminizaron generizadamente al cuerpo, estimulando la diferenciación sexual y corporal. En el caso de la descripción del cuerpo femenino, se tomó como referencia al varón como criterio para calificarlo y clasificarlo. ${ }^{52}$ La educación sexual se

\footnotetext{
492 de agosto de 1921. AIN, Caja 3. Fondo: CNE, 1921, folio 22.

502 de agosto de 1921. AIN, Caja 3. Fondo: CNE, 1921, folio 22.

${ }^{51}$ AIN, Caja 3. Fondo: CNE, 1921.

52 Pablo Scharagrodsky, «Entre la maternidad y la histeria. Medicina, prácticas corporales y feminidad en el Buenos Aires del fin de siglo XIX», en Gobernar es ejercitar. Fragmentos históricos de la
} 
reducía, en el sistema escolar, a la enseñanza de las labores femeninas y a los conocimientos sobre la maternidad.

Hasta aquí el inspector solo atinó a recabar información. En uno de sus informes estimaba que no se podía comprobar el alcoholismo de Q. ni los hechos denunciados más allá de la carta. Sin embargo, consideraba que Q. no era el indicado para ocupar el puesto de director debido a sus falencias técnicas y a su pobre cultura general, y que un pueblo que había llegado al grado de población escolar y desarrollo material, como Comodoro Rivadavia no se lo merecía. ${ }^{53}$

El funcionario nunca mencionó un acto de acoso. El inspector entendía que había una situación de cortejo sentimental intolerable entre un director casado y una maestra bajo su supervisión. Y esta era una grave infracción moral que ameritaba sanciones disciplinarias acorde a los digestos escolares que prohibían las relaciones sentimentales entre maestros/as.

Hay que señalar que el debate en torno a la definición de acoso está aún en boga en la actualidad. El imaginario colectivo que ligaba al magisterio o a la maestra con la «pureza», el «sacerdocio» o la «maternidad» se oponía a los espacios en donde la belleza se veía derogada por el trabajo duro, repetitivo y alienado encarnado en la fábrica. La figura de la maestra se oponía a la imagen de la obrera. La fábrica era el escenario propicio para que el mundo moral se desmoronara: los abusos patronales abarcaban desde el sexual, la extensión de la jornada y los actos de violencia cometidos contra las mujeres. El ingreso femenino al mercado laboral estaba plagado de estos peligros, que ponían en jaque el orden familiar, el honor y el respeto. Así, el magisterio podía resultar en un ámbito laboral de mayor seguridad y resguardo moral para las mujeres que elegían la docencia, ya que el sistema escolar de la época era un engranaje de apariencias traslucido en la estética escolar, la producción de materiales instructivos con formatos y lenguajes específicos, códigos de vestimentas y conductas naturalizadas como correctas.

Educación Física en Iberoamérica, comp. Pablo Scharagrodsky (Buenos Aires: Prometeo, 2008), 105136.

53 AIN, Caja 3. Fondo: CNE, 1921. 


\section{DOBLE MORAL Y SOLTERÍA}

El cargo jerárquico del director merecía una vida personal ordenada y alejada de los conflictos y los placeres mundanos. Sin embargo, era vox populi que el varón podía permitirse una licencia sexual requiriendo los placeres de una prostituta o una amante. En cambio, el placer sexual de las mujeres se reducía a la búsqueda de la futura prole. Al respecto, el historiador Pablo Ben ha señalado que la Buenos Aires de principios del siglo XX, como otras tantas urbes, estuvo marcada por una sexualidad profusa y ajena a la vida matrimonial. ${ }^{54}$ Según el director, la provocación, las insinuaciones y la debilidad carnal se correspondían con la conducta indecorosa de la maestra y su situación civil, lo que suponía un problema de raíz biológica. Reconocía la autoría de la carta, pero en el trasfondo de su relato dejaba entrever que su masculinidad poseía un componente natural que no resistía los encantos del sexo opuesto. ${ }^{55}$

La soltería se tornaba así en un problema de histeria femenina, un condicionante para constituir relaciones heterosexuales estables, construir una familia y generar una descendencia sana. Si bien para los varones la soltería podía implicar una instancia de aventuras amorosas, para las mujeres se transfiguraba en un estigma. Ellas podían caer en la histeria por sus condicionantes biológicos, como la menstruación; que requería ser entendida como una patología, según los criterios científicos de la época. ${ }^{56}$

De más está decir que la «mujer solterona» atentaba contra el ideal familiar esbozado por la tradición católica, imperante aún en los discursos de las agencias estatales y, sobre todo, dentro del ámbito escolar. Como ha señalado Barrancos, a pesar de la secularización por la que atravesó el país a fines del siglo XIX, la moral religiosa era reforzada por la moral republicana, en la cual la familia era un actor sustancial.

Lo cierto es que la justificación masculina contra la denuncia era la conducta irreverente de una solterona poco proclive a aceptar las normas

\footnotetext{
${ }_{54}$ Pablo Ben, «La ciudad del pecado: moral sexual de las clases populares en la Buenos Aires del 900», en Moralidades y comportamientos sexuales. Argentina, 1880-2011, ed. Dora Barrancos, Donna Guy y Adriana Valobra (Buenos Aires: Biblos, 2014), 95-114.

${ }_{55}$ Caldo, «Entre amores clandestinos y cesantías», 155.

${ }^{56}$ Ver: Nari, Políticas de maternidad.
} 
escolares. No convencido, el inspector Roberts continuó recabando testimonios ante el vecindario yendo a los domicilios particulares. Por su parte el personal docente, por medio de un telegrama, brindó apoyo al director. ${ }^{57}$ Para el visitador escolar, la única prueba contra Q. era la carta, que contaba con un carácter repugnante y lascivo.

En septiembre de 1923 Clorinda renunció a su cargo debido a que al director no le dispensaban una sanción. Tiempo después de su renuncia el director fue exonerado y concurrió a Capital Federal con la intención de que revieran su situación. Al parecer sus influencias dentro del CNE, un importante gerente de banco, un coronel y exfuncionario del CNE consiguieron hacer efectiva la demanda de Q.: logró que lo trasladaran al kilómetro 3, en Niñas de Petróleo del Estado. A fin de ese año, se produjo el traslado del maestro a la escuela $\mathrm{N} .^{\circ} 2$, que funcionaba en el campamento petrolero de kilómetro 3. Luego, en 1927, resultó trasladado a La Pampa. ${ }^{58}$

Mientras que Q. siguió ejerciendo la docencia, hacia 1935 la maestra se había quedado sin empleo y su madre había fallecido. El 4 de abril de ese año, desde la provincia de San Luis, pidió al CNE un puesto de maestra en cualquier escuela. ${ }^{59} \mathrm{El}$ presidente del CNE resolvió el 7 de agosto de 1935 no hacer lugar al pedido de reincorporación. Sin embargo, sabemos que en 1943 Clorinda recibió una pensión que le permitió atenuar sus penurias cotidianas. ${ }^{60}$

\section{5, RÍO NEGRO. CASO DOMINGA: LA MAESTRA QUE NO QUERÍA SER TRASLADADA}

La consolidación del Estado nacional a fines del siglo XIX tras la conquista militar de las comunidades nativas tenía como objetivo la ocupación del territorio y la delimitación geográfica con Chile. En 1878

\footnotetext{
57 Telegrama dirigido al CNE. AIN, Caja 3. Fondo: CNE, 1921, folio 69.

58 "La escuela 83 tiene el orgullo de ser la más antigua de Comodoro», El Patagónico, 23 de febrero de 2012. https://www.elpatagonico.com/la-escuela-83-tiene-el-orgullo-ser-la-mas-antigua-comodoro-n615859 (consultado el 12-10-2019).

59 Nota dirigida al presidente del CNE, Octavio Pico, 4 de abril de 1935. AIN, Caja 3. Fondo: CNE, 1921.

${ }^{60}$ Buenos Aires, 7 de agosto de 1935. AIN, Caja 3. Fondo: CNE, 1921.
} 
el presidente Avellaneda envió al Congreso un proyecto que ordenaba la ocupación de Río Negro como frontera de la República. Tras la Conquista del Desierto (1879) se creó en 1883 Colonia Roca, en la provincia de Río Negro. La colonia se transformó en un gran centro agrícola y foco de atracción para los inmigrantes. Entre 1909 y 1919 se desarrollaron las obras de riego, se incrementó el comercio y la inmigración y se tendieron las redes eléctricas para el alumbrado público. La educación también se expandió con la congregación salesiana. ${ }^{61} \mathrm{~A}$ principios del siglo XX, Río Negro tenía una población urbana del 37\% y un 63\% rural; las principales poblaciones estaban en Bariloche, Viedma, General Roca, San Antonio Oeste, Buena Parada y Río Colorado.62 Entre 1900 y 1914 hubo un sostenido crecimiento de las escuelas más allá de la falta de presupuesto público.

Dominga vivía en General Roca, contaba con un título provincial para ejercer la docencia y desde joven se había dedicado al magisterio. En el año 1935, con 21 años de servicios, trabajaba en la escuela N. ${ }^{\circ} 3$. Próxima a jubilarse, gozaba de ser una maestra de primera categoría. Su vida personal no había sido grata. Su salario no le alcanzaba para cubrir todas sus necesidades familiares, aunque como han demostrado otras investigaciones, el salario de las maestras era el mismo que sus pares docentes masculinos, a diferencia de lo que acontecía con las obreras, las empleadas administrativas o de escritorio (dactilógrafas, taquígrafas y secretarias). En el año 1920 su esposo la había abandonado y había tenido que educar en soledad a sus hijos de cinco y dos años.

El 1 de marzo de 1935 se anotició de la resolución de traslado pedida por el director de la escuela. El 3 de abril, Dominga elevó al inspector seccional de escuelas nacionales, Arnobio O., el pedido de una investigación sumaria con el fin de aclarar las causas que habían motivado su traslado intempestivo a la escuela N. ${ }^{\circ} 132$ de La Parra, a 16 leguas de General Roca. Al igual que en los casos anteriores, los comentarios en el

\footnotetext{
${ }^{61}$ La congregación salesiana llegó a Argentina en el año 1877 con la misión de evangelizar, educar y «civilizar» a los aborígenes radicados en Patagonia. Ver: María Alejandra Estrada, «¿Mesianismo salesiano en Patagonia septentrional? Último cuarto del siglo XIX, pueblo General Roca», Revista Española de Antropología Americana 41, no. 1 (2011): 97-116. https://doi.org/10.5209/rev_REAA.2011. v41.n1.5 (consultado el 12-10-2019).

62 Cincuentenario de la ley 1420. Tomo II: Memoria sobre el desarrollo de las escuelas primarias desde 1884 a 1934 (Buenos Aires: Consejo Nacional de la Educación, 1938).
} 
pueblo instigaban las sanciones por supuestas inmoralidades. Un indicio de las acusaciones recibidas se encuentra en una de las notas, en donde Dominga pedía la revisión de su caso al CNE:

[...] no he procedido ilícitamente para aumentar mis recursos. Tengo para atestiguar mi proceder honrado y mi moralidad en el pueblo y mi vida privada, a los señores dueños de la casa, donde he estado de pensionista, habiendo estado 8 años seguidos en una sola casa de familia; 4 en otra y 3 en la que actualmente estoy quienes pueden informar cuál es mi moralidad y régimen de vida. ${ }^{63}$

El 13 de marzo la maestra había sido requerida por el director de la escuela, quien la había anoticiado de su traslado. Pensó que se estaba cometiendo una injusticia, ya que el viaje cotidiano lesionaría aún más su bolsillo ajustado. Discutió con el director, rechazando la medida, y fue prácticamente echada del despacho. En medio del altercado, se enteró de que su puesto ya estaba ocupado y de que no podía presentarse en la escuela, bajo amenaza del director de sacarla. El nerviosismo hizo mella en su cuerpo así que concurrió inmediatamente al médico escolar, quien le expidió un certificado por ocho días de licencia.

Dominga sentía un gran rechazo, a juzgar por sus notas y pedidos, por el director de la escuela que desde su óptica había provocado todo este asunto. En todo el expediente, el jerárquico solo aparece una vez, por medio de una nota elevada al inspector seccional, donde desestimaba el pedido de reconsideración de la maestra con respecto al traslado. A renglón seguido esgrimía:

Bajo el aspecto moral, la conducta de la recurrente hace ya varios años - antes de que el suscrito fuese Director de esta Escuela-, dio motivo a la intervención de la Superioridad. Antes de aquella investigación, esa señora vivía ya separada del esposo y de los hijos y sigue hasta hoy separada de ellos. Ignora el suscrito si la comprobación de las acusaciones que se referían a su conducta íntima, a su vida de privada - y que tuvieron trascendencia pública - fue o no establecida; pero no ignora que las causas

\footnotetext{
${ }^{63}$ AIN, Caja 54. Fondo: CNE, 1934.
} 
externas que la motivaron [...] y si el suscrito no las tenido en cuenta, al formular sus conceptos; ha sido porque —además de la aversión y repugnancia que siente para apreciar la vida privada de nadie- los antecesores y Superiores tampoco quisieron tocar ese delicado aspecto [...]. ${ }^{64}$

Pero el director iba más allá de las acusaciones en torno a la moralidad de la maestra. A esto se sumaba el «afán morboso y perturbador» de ocuparse de la conducta de las «personas agenas [sic], de indisponer unas contra otras...». Por último, para el maestro, las condiciones técnicas eran «tan escasas [...] que no la consideré nunca necesariamente indispensable para un tercer grado». ${ }^{65}$ Sin embargo, uno de los fundamentos de Dominga fue su reciente ascenso a maestra de primera categoría, que se realizaba por mérito y antigüedad.

Si la labor de la maestra pecaba de falencias técnicas, ¿por qué se le había otorgado este merecimiento? Era evidente que el director incurría en una contradicción. Aunque el CNE aclaró que no había denuncias contra su persona, Dominga intentó persuadir a las autoridades del CNE para exponer el nombre del denunciante y realizar una denuncia penal, ya que sus intereses morales habían sido ultrajados. ${ }^{66}$

Las acusaciones y denuncias se entrecruzaron entre la maestra y el director. Dominga no se mantuvo en una posición sumisa:

Yo acuso al señor Director Don Edmundo G. de ser el culpable de mi traslado, pues se jacta de haberlo pedido y conseguido y de haber pedido también el de otros compañeros [...] Acuso al señor Director G. de las siguientes graves irregularidades: haber permitido a las maestras de $5^{\circ}$ y $6^{\circ}$ el año pasado hacer colectas entre los alumnos [...] de haberme llamado para retarme en la dirección [...] esto puede investigarse en el Pueblo, que es el que habla y él que puede justificar las afirmaciones del señor Director $[\ldots]^{67}$

\footnotetext{
646 de mayo de 1935. AIN, Caja 54. Fondo: CNE, 1934.

65 AIN, Caja 54. Fondo: CNE, 1934.

668 de noviembre de 1935. AIN, Caja 54. Fondo: CNE, 1934.

${ }^{67}$ General Roca, 3 de abril de 1935. El Reglamento general de escuelas impedía realizar colectas entre los alumnos/as.
} 
Otras de las acusaciones contra el director describían las escenas donde el jerárquico redactaba las actas de reuniones de los maestros/as en borrador, y las amenazas trasladadas o exoneraciones al personal docente. Tanto la maestra como el director apelaban al «pueblo» como testigo de sus buenas conductas y el buen desempeño dentro de la escuela. Y es que «el pueblo» o las sociedades locales tenían una relación horizontal con las escuelas, ya que el CNE promovió la integración de las familias en la labor educativa. Por ejemplo, las medidas tendientes a la integración de la comunidad a la obra escolar en el caso de Río Negro implicó tres instancias conciliadoras: los actos de fin de curso, las conferencias públicas impartidas por los docentes en las comunidades locales y las impresiones que debían despertar los maestros en el medio social.68

La Asesoría Letrada intervino ante la insistencia de la docente, pero no hizo lugar a lo solicitado. Sin embargo, el argumento pareciera ser diferente: el traslado dispuesto, según la Asesoría, no tuvo carácter disciplinario ni tampoco fue el resultado de denuncia alguna. La medida habría sido «de carácter bastante general fundada en consideraciones de buen gobierno escolar al considerarse la reorganización de las Escuelas de Río Negro».69

Dominga fue a Buenos Aires con una fuerte depresión para hablar con los funcionarios del CNE. Logró entrevistarse con el Dr. José Rezzano, quien se demostró extrañado y prometió enterarse de lo ocurrido. ${ }^{70}$ También hizo conocer su situación al vicepresidente del CNE, Dr. Feliz Garzón Maceda, quien prometió hacer justicia. Pero Dominga no estaba sola en esta trama: un "viejo y respetable amigo», un coronel, enterado de lo ocurrido, la acompañó. Según Dominga, el inspector general, encargado del caso, utilizando una serie de términos que menoscababan su buen nombre de mujer y de maestra, manifestó que se la había trasladado por razones de inmoralidad. Rezzano hizo llamar al inspector general y este se expresó en los mismos términos con respecto a

\footnotetext{
${ }_{68}$ Cielo Zaidenwerg, «La argentinización de los territorios nacionales a través de la educación formal e informal. Estudio de caso Río Negro (1908-1930)» (Tesis doctoral, Universidad de Barcelona, 2013), 281.

${ }^{69}$ Asesoría Letrada, 18 de marzo de 1936. AIN, Caja 54. Fondo: CNE, 1934.

70 José Rezzano (1877-1960) fue médico, maestro y profesor normal en la escuela «Mariano Acosta» de Capital Federal y una figura destacada del magisterio argentino. Ocupó la Inspección Técnica General de las escuelas de Capital durante la presidencia de Hipólito Yrigoyen (1916-1922).
} 
Dominga: según el funcionario, la maestra era una mujer de mala vida. El inspector también manifestó que el traslado había sido aconsejado por la Inspección Seccional.

\section{LEJANÍA, DESTIERRO E INJUSTICIAS}

Sin perder su insistencia, Dominga apeló a la autoridad máxima. El 5 de abril de 1935 la maestra le escribió al presidente del CNE, Octavio Pico:

[...] viaje a esa Capital sin antes tener que vencer muchos inconvenientes a fin de expresar a usted mi inocencia y pedir justicia, pero por muchos esfuerzos [...] no tuve la suerte de conseguir durante los 15 días de estadía poder hablar con V.E. [...]. Vuelvo ante V.E., solicitando se practique una investigación sumaria al Director de la Escuela N. ${ }^{\circ} 32$, Sr. Edmundo G., quien es el culpable de esto y cumpliendo las continuas amenazas de hacernos trasladar o hechar [sic] de nuestro puesto [...] Pido a V.E. se me pase a la Escuela N. ${ }^{\circ} 42$, cargo que me corresponde por antigüedad, conceptos y categoría [...].71

Para Dominga, el traslado era una sanción ilegítima equivalente a un destierro simbólico, que lesionaba su labor de maestra, su integridad de mujer y, por cierto, su exigua economía. Las escuelas creadas por el CNE en los territorios nacionales o en las provincias muchas veces estaban rodeadas por la soledad del paisaje en espacios geográficos del difícil acceso.

La descripción de Dominga sobre la escuela N. ${ }^{\circ} 132$ de La Parra y sus posibilidades de hospedaje presentaban las características anteriormente señaladas. A ello se sumaba un pequeño logro material que veía peligrar por su traslado luego de años de penurias, ya que en La Parra

no hay casas para hospedarse y para concurrir la menor distancia que recorrería son tres leguas, que en ida y vuelta suman 6, habiendo necesidad de un medio de movilidad, lo que me sería muy costoso a la par que molesto. Bajo ningún punto me conviene salir de este pueblo, donde recién he podido acogerme a los beneficios del

715 de abril de 1935. AIN, Caja 54. Fondo: CNE, 1934. 
Banco Hipotecario y comprar por su intermedio una casita donde vivir con mis dos hijitos, más tranquila después de 21 años de lucha y mil privaciones. No es justo que por un capricho del Director se me destierre $[\ldots] .72$

Paralelamente, la maestra no se amilanó y entendió que debía denunciar penalmente al director de la escuela por calumnias e infamias. Sin embargo, todas estas gestiones fueron infructuosas ya que, transcurrido un año, Dominga se veía aún más malograda. Seguía en la escuela a la que había sido trasladada, teniendo que viajar diariamente y sufriendo las mortificaciones del viaje, agravada por las reducciones del presupuesto, ya que los medios de movilidad costaban entre 65 y 70 pesos mensuales.

Tras el silencio del CNE, Dominga se dirigió al Frente Único del Magisterio Argentino para que intercediera ante el presidente del CNE el pedido de reconsideración. Su presidente, E. Nieto de la Vega, fue quien se encargó del pedido. ${ }^{73}$ Inmediatamente el presidente del CNE, Octavio Pico, respondió que el organismo no había podido rever la resolución por la cual se trasladaba a la docente en razón de ciertas causas de orden moral que no se podían detallar.

El tiempo coyuntural tampoco le era favorable a la maestra. Hay que señalar que en la década de 1930, tras el golpe militar de José Félix Uriburu, el CNE se reconfiguró con funcionarios adscriptos a la ideología del nacionalismo y del catolicismo, entre ellos, Octavio Pico. ${ }^{74}$ Los discursos escolares profundizaron las concepciones morales, reforzaron los estereotipos de género y la persecución a la alteridad ideológica, exonerándose a varios maestros/as acusados de propagar ideologías foráneas como el marxismo. ${ }^{75}$

\footnotetext{
72 Nota al presidente del CNE, 5 de abril de 1935. AIN, Caja 54. Fondo: CNE, 1934.

73 Frente Único del Magisterio. Buenos Aires, 17 de octubre de 1935.

${ }^{74}$ Uno de estos fue Juan B. Terán, quien asumió el cargo de presidente del CNE bajo la dictadura de Uriburu (1930-1932). Terán era un espiritualista, antilaicista y conservador que repudiaba la Reforma Universitaria de 1918 y la Escuela Activa. A Uriburu le sucedió en el gobierno Agustín P. Justo (1932-1938), quien puso su foco de atención y persecución sobre los docentes que tenían posturas más críticas, radicalizadas o laicistas. En el CNE Terán fue reemplazado hacia 1932, nombrado por el presidente Justo, el ingeniero Octavio Pico.

75 Ver: Adrián Cammarota, «El caso de los maestros comunistas y el Diario Crítica (1933-1940)», Revista Pilquen 22, no. 1 (2019b): 1-12.
} 
Dominga volvió a insistir y envió una nota al inspector general de Escuelas, J. Oliver, en 1935. La nota apelaba al «honor», a la "digna intervención», y a la «justicia de los hombres» que actuaban en la repartición como funcionarios. A renglón seguido, la maestra escribió a que el inspector podía

medir la magnitud de la injusticia calumniosa que se cometió conmigo, con la maestra que dio todo y no escatimó sacrificio en pos de los niños y que esto fue el fruto recibido después de tantos años de lucha continuados [...].

Insisto en que se debe levantar una investigación sumaria en la escuela N. ${ }^{\circ} 32$ de fuerte General Roca, Río Negro [...] por ser el móvil, el espíritu mezquino y ruin de ese hombre que sin título de maestro ejerce la dirección de la mencionada escuela y que envalentonado por las influencias políticas (socialistas) comete con los maestros las arbitrariedades que son de dominio público $\left[\ldots . .{ }^{76}\right.$

Era evidente que la apelación a la peligrosidad de la alteridad ideológica era un recurso de defensa. Al igual que en el caso de Paulina, la puja por criterios de justicia se entrecruzaba con la amenaza que suponían las ideologías foráneas que, a juicio de la maestra, amenazaban la vida cotidiana de la escuela y conducían a gestiones arbitrarias y a medidas punitivas:

[...] he sufrido casi dos años el peso de la calumnia y el rigor del castigo, porque yo así lo considero, pero en ningún momento permanecí callada, habiendo el Honorable Consejo Nacional de Educación acordando a mi favor resoluciones que no han satisfecho mi dignidad de mujer y si hasta se quiere como maestra $[\ldots] . .^{77}$

Las promesas de los funcionarios a la maestra no tuvieron real incidencia. Dominga escribía que seguía la lucha completamente sola, sin ayuda de nadie, esperando el "castigo terrenal» y la "justicia divina». Sin embargo, sus interpelaciones alcanzaron un logro parcial: el 24 de

\footnotetext{
${ }^{76}$ Nota al inspector general de escuelas, 1935. AIN, Caja 54. Fondo: CNE, 1934. Ante la necesidad apremiante de cubrir la demanda de maestros/as, el CNE autorizó el ejercicio de la docencia a hombres y mujeres que no poseían las credenciales académicas otorgadas en las escuelas normales.

77 Nota al inspector general de escuelas, 1935. AIN, Caja 54. Fondo: CNE, 1934.
} 
junio de 1935 el CNE resolvió que la trasladaran de la escuela N. ${ }^{\circ} 132$ de La Parra a la escuela N. ${ }^{\circ} 38$ de General Roca, cercana a su domicilio. ${ }^{78}$ Para su exigua economía de maestra fue un alivio; sin embargo, el pedido de apertura de un sumario sobre el director de su antigua escuela fue desestimado.

\section{A MODO DE CIERRE}

Durante las primeras décadas del siglo XX, la escuela, como microfísica del poder, intentó detectar las anormalidades de los niños/as y adultos docentes y moldear las subjetividades en pos de una identidad nacional. También forjó determinados estereotipos de género con un currículum oculto que contribuyó históricamente a transmitir un mensaje estereotipado y diferenciador. En este sentido, los casos de las maestras y la intervención de la burocracia educativa, con el procedimiento estipulado en el Reglamento de sumarios, exponían el entroncamiento de los mecanismos de control y disciplinamiento con base en la sexualidad y la moral que se extendían por fuera del perímetro escolar. Los casos demuestran que existía una disputa explícita por ejercer el control sobre la esfera privada y pública de las maestras.

De esto se desprende el hecho de que la organización escolar no era un espacio aislado, sino que mantenía y mantiene en la actualidad relaciones horizontales con la sociedad, reproduciendo esquemas de poder, jerarquías, desigualdades y representaciones. Las comunidades locales fueron un factor testimonial de las conductas correctas avaladas por las convenciones sociales. En todos los casos investigados, los inspectores relevaban opiniones o pareceres sobre la moralidad de los involucrados/ as. Vemos entonces que son los varones los que acusan, llevan adelante los procesos investigativos, aplican las sanciones y las exoneraciones. Las mujeres cuestionan su proceder e intentan anular las acusaciones, no así su autoridad de funcionarios varones. Incluso apelan a determinadas figuras masculinas para la defensa de sus puestos laborales y de su honor. Y esto en parte se debe a que las biografías de estas mujeres estaban atadas a las estructuras institucionales y a la jurisprudencia de la época, que, si bien entre la década de 1920 y 1930 sufrió cambios

\footnotetext{
${ }^{78}$ Resolución del CNE, 24 de junio de 1935.
} 
sustanciales, no modificaron los prejuicios sobre el lugar y el comportamiento que debían mostrar las mujeres, sobre todo, como ya señalamos, si ellas ejercían el magisterio.

Paulina, Clorinda y Dominga tienen una historia en común: eran maestras y mujeres solas afectivamente. La soledad es una experiencia subjetiva y universal del ser humano; sin embargo, en la tónica de la época, el trato social en la vida cotidiana de las mujeres estaba construido para impedir la soledad, que insinuaba negación al matrimonio o la indefensión frente a las vicisitudes de la vida. Como ha señalado Lagarde, la construcción de la relación entre los géneros tiene históricamente múltiples implicaciones, y una de ellas es que el sosiego de las mujeres depende de la presencia de los hombres. En la ética cultural asignada a las mujeres no está presente la autonomía; por el contrario, la formación de género es la ética de la fusión, de la inexistencia autónoma del género femenino. ${ }^{79}$ Esta aseveración trasunta en la construcción experiencial de las tres maestras. La casi ausencia masculina y protectora del varón dentro de sus círculos sociales las expuso a los comentarios insidiosos y a la mirada inquisidora de la jerarquía masculina escolar. Para Clorinda, la denuncia abrió un campo minado de representaciones sobre las mujeres que quedaron niveladas en las justificaciones del director en torno a la figura femenina. La soltería de la maestra fue uno de los puntales acusados por el director como prueba de la provocación sexual de la docente.

Ahora bien, ¿por qué las denuncias o comentarios ponían en tensión los valores sostenidos por el magisterio? Los resquicios de los casos señalados lesionaban el ideal de maestra esbozado en los discursos escolares y sostenidos por mandatos socioculturales. La vida privada de estas mujeres, cuyo modelo familiar se alejaba del propuesto en el ámbito escolar, y sus supuestas inmoralidades, ponían en tensión los valores que el magisterio fraguó sobre los pilares de un currículum escolar que justificaba las diferencias de género, en donde varones y mujeres tenían roles culturalmente asignados. El carácter disciplinante del magisterio se podía extender a las emociones y a la vida privada de los miembros de la comunidad escolar. Para los funcionarios del CNE, la conducta de Paulina y Dominga eran actos ilegítimos que atentaban

\footnotetext{
79 Marcela Lagarde, Claves feministas para el poderío y la autonomía de las mujeres. Memoria. (Managua: Puntos de Encuentro, 1997), 11.
} 
contra el modelo familiar, las buenas costumbres y el «buen gobierno escolar». Podemos hipotetizar que los cánones varoniles de la época y la condición de mujeres solas las exponía a los condicionamientos morales y prejuicios de los vecinos.

Las conductas «inmorales» en el caso de Dominga nunca son descriptas por la burocracia educativa interviniente, aunque representaban una falta grave a los ojos de los funcionarios, lo mismo que en el caso de Paulina. El caso de Clorinda es más complejo debido a que la investigación se abrió gracias a la denuncia realizada por el hermano ante una relación sentimental que luego, a juzgar por lo que describe la maestra, terminó transformándose en un hecho de acoso por parte del director. Según se desprende de los derroteros de la investigación, el acoso del varón no tenía la misma reputación que las supuestas conductas indecorosas de las maestras que, para la burocracia educativa, estaban reñidas con la naturaleza femenina y el rol docente.

Sin embargo, el posicionamiento frente a los funcionarios de las tres maestras se subsume en un grado de debilidad. La soledad y la vida material empobrecida reducen el margen de acción para sus defensas personales. Empero, las mujeres aquí mencionadas no fueron pasivas. A su modo y apelando a diversas estrategias o estilos discursivos que podían reproducir estereotipos masculinos, y por medio de los mecanismos pautados por la normativa escolar, las maestras interpelaron a los funcionarios en defensa de sus puestos laborales y de su honor. Por lo tanto, en el caso de Dominga como en el de Paulina y en el de Clorinda, se pueden vislumbrar los canales a través de los cuales se ponen en juego el control, la apropiación, la negociación, la resistencia y el poder en la construcción cotidiana de las culturas escolares.

\section{Nota sobre el autor}

Adrián Cammarota es Doctor en Ciencias Sociales (UNGS-IDES), Magister y Licenciado en Historia (UNTREF). Se desempeña como profesor e investigador adjunto del CONICET con lugar de trabajo en la Universidad Nacional de La Matanza (Buenos Aires, Argentina). Autor de diversos trabajos sobre historia de la salud e historia de la educación, de la niñez y de la juventud desde una perspectiva socio-cultural; entre sus 
producciones se destacan "Somos bachiyeres" Juventud, cultura escolary peronismo en el Colegio Nacional Mixto de Morón (1949-1959) (Buenos Aires: Editorial Biblos, 2014).

\section{REFERENCIAS}

Allport, Gordon y Leo Postman. Psicología del rumor. Buenos Aires: Editorial Psique, 1973.

Andújar, Andrea. "Historia social del trabajo y género en la Argentina del siglo XX: balance y perspectivas». Revista Electrónica de Fuentes y Archivos (REFA) 8, no. 8 (2017): 43-59. https://refa.org.ar/file.php?tipo=Contenido\&id=172

Barrancos, Dora, Donna Guy y Adriana Valobra. Moralidades y comportamientos sexuales. Argentina, 1880-2011. Buenos Aires: Biblos, 2014.

Barrancos, Dora. "Moral sexual, sexualidad y mujeres trabajadoras en el período de entreguerras». En Historia de la vida privada en la Argentina. Tomo 3: La Argentina entre multitudes y soledades. De los años 30 a la actualidad, dirigido por Fernando Devoto y Marta Madero, 199-225. Buenos Aires: Taurus, 1999.

Becerra, Marina. «Un prisma original: educación, género, amor y ciudadanía en Herminia Brumana». Anuario de historia de la educación 17, no. 2 (2016): 80-103.

Ben, Pablo. «La ciudad del pecado: moral sexual de las clases populares en la Buenos Aires del 900». En Moralidades y comportamientos sexuales. Argentina, 1880-2011, editado por Dora Barrancos, Donna Guy y Adriana Valobra, 95-114. Buenos Aires: Biblos, 2014.

Bertoni, Lilia. Patriotas, cosmopolitas y nacionalistas. La construcción de la nacionalidad argentina a fines del siglo XIX. Buenos Aires: Fondo de Cultura Económica, 2001.

Billorou, María José. «Mujeres que enseñan no solo en las aulas: docentes en el interior argentino en la primera mitad del siglo XX». Anuario de historia de la educación 17, no. 2 (2016): 57-79

Bracamontes, Lucía. «Mujeres, trabajo y educación a principios del siglo XX: las maestras en la prensa católica del sudoeste bonaerense argentino». Diálogos, Revista Electrónica de Historia 12, no. 1 (2011): 101-127.

Bunge, Alejandro. Una nueva Argentina. Buenos Aires: Hyspamerica, 1984 [1940].

Caldo, Paula. «Entre amores clandestinos y cesantías. La maestra y el director, Argentina, 1920-1928». Géneros 26, no. 26 (2019): 145-163.

Caldo, Paula. «No parecían mujeres, pero lo eran. La educación femenina de las maestras, Argentina, 1920-1930». Historia y sociedad 26 (2014): 237-265. http://www.scielo.org.co/scielo.php?pid=S012184172014000100010\&scrip$\mathrm{t}=\mathrm{sci} \_$abstract\&tlng $=\mathrm{pt}$ 
Cammarota, Adrián. «El caso de los maestros comunistas y el Diario Crítica (1933-1940)». Revista Pilquen 22, no. 1 (2019b): 1-12. http://revele.uncoma. edu.ar/htdoc/revele/index.php/Sociales/article/view/2239/pdf

Cammarota, Adrián. "Nacionalizar y educar: algunos problemas de la educación común en los territorios nacionales (1890-1940)». Avances del Cesor (2019) (en prensa).

Cosse, Isabella. Estigma de nacimiento. Peronismo y orden familiar, 1946-1955. Buenos Aires: Fondo de Cultura Económica, 2006.

Estrada, María Alejandra. «¿Mesianismo salesiano en Patagonia septentrional? Último cuarto del siglo XIX, pueblo General Roca». Revista Española de Antropología Americana 41, no. 1 (2011): 97-116. https://doi.org/10.5209/ rev_REAA.2011.v41.n1.5

Fiorucci, Flavia. «Los amores de la maestra: sexualidad, moral y clase durante el peronismo». Secuencia 85 (2013). http://www.scielo.org.mx/scielo.php?script=sci_arttext\&pid=S018603482013000100003

Fiorucci, Flavia. «País afeminado, proletario feminista. Mujeres inmorales e incapaces: la feminización del magisterio en disputa (1900-1920)». Anuario de Historia de la Educación 17, no. 2 (2016): 120-137. http://ppct.caicyt.gov. ar/index.php/anuario/article/view/9793

González Leandri, Ricardo. «La elite profesional docente como fracción intelectual subordinada. Argentina: 1852-1900». Anuario de Estudios Americanos 58, no. 2 (2001): 513-535. http://estudiosamericanos.revistas.csic.es/index.php/estudiosamericanos/article/view/214

Jorba, Rodolfo Richard. «Somos el Pueblo y la Patria. El populismo lencinista en Mendoza frente al conflicto social y la prensa: discursos, representaciones y acciones, 1917-1919». Revista de Historia Americana y Argentina 48, no. 1 (2013):11-54.

Lagarde, Marcela. Claves feministas para el poderío y la autonomía de las mujeres. Memoria. Managua: Puntos de Encuentro, 1997.

Lobato, Mirta. Historia de las trabajadoras en la Argentina (1869-1960). Buenos Aires: Edhasa, 2007.

Míguez, Enrique. "Familias de clase media: la formación de un modelo». En Historia de la clase media en la Argentina. Tomo II: La Argentina plural (18701930), dirigido por Fernando Devoto y Marta Madero, 21-45. Buenos Aires: Taurus, 2010.

Morgade, Graciela. Mujeres en la educación: género y docencia en la Argentina: 1870-1930. Buenos Aires: Miño y Dávila, 1997.

Nari, Marcela. Políticas de maternidad y maternalismo político. Buenos Aires, 1890-1940. Buenos Aires: Biblos, 2004.

Pagés-Rangel, Roxana. Del dominio público: Itinerarios de la carta privada. Ámsterdam-Atlanta: Rodopi, 1997. 
Pellegrini, Micaela. «Huelgas, maestras y rumores. Una escena de mujeres en lucha a partir de un estudio de caso (FIRMAT, Argentina, 1921)». La Ventana 49 (2018): 283-316.

Pita, Valeria. «De negociaciones cotidianas y de posibilidades históricas: una aproximación a los intercambios entre médicos y trabajadoras. Buenos Aires, 1870, 1940». Anuario de Historia Regional y de las fronteras 19, no. 2 (2014): 365-390.

Puiggrós, Adriana. Sujetos, disciplina y currículum en los orígenes del sistema educativo. Buenos Aires: Galerna, 1990.

Queirolo, Graciela. Mujeres en las oficinas. Trabajo, género y clase en el sector administrativo. Buenos Aires, 1910-1950. Buenos Aires: Biblos, 2019.

Ramacciotti, Karina. "Profesiones sanitarias, género e historia». Avances del Cesor 13 (2016): 81- 92.

Scharagrodsky, Pablo. «Entre la maternidad y la histeria. Medicina, prácticas corporales y feminidad en el Buenos Aires del fin de siglo XIX». En Gobernar es ejercitar. Fragmentos históricos de la Educación Física en Iberoamérica, compilado por Pablo Scharagrodsky, 105-136. Buenos Aires: Prometeo, 2008.

Scott, Joan. Only Paradoxes to Offer. French Feminists and the Rights of Man. Cambridge: Harvard University Press, 1996.

Viñao Frago, Antonio. Sistemas educativos, culturas escolares y reformas: continuidades y cambios. Madrid: Morata, 2002.

Wainerman, Catalina. "Mujeres que trabajan. Hechos e ideas». En Población y bienestar en la Argentina del primero al segundo centenario. Una historia social del siglo $X X$, compilado por Susana Torrado, 327-352. Buenos Aires: Edhasa, 2007.

Yannoulas, Silvia. «Acerca de cómo las mujeres llegaron a ser maestros (América Latina, 1870-1930)». Rev. Bras. Estud. Pedagog. 73, no. 175 (1992): $497-$ 521.

Yannoulas, Silvia. Educar, ¿una profesión de mujeres? La feminización del normalismo y la docencia (1870-1930). Buenos Aires: Kapelusz, 1996.

Zaidenwerg, Cielo. «La argentinización de los territorios nacionales a través de la educación formal e informal. Estudio de caso Río Negro (1908-1930)». PhD diss., Universidad de Barcelona, 2013. 